\title{
Konaklama İşletmelerinde Hedef Maliyetleme, Değer Analizi ve Kaizen Maliyetleme Yöntemlerinin Birlikte Uygulanabilirliğine İlişskin Bir Araştırma
}

\author{
Ercüment OKUTMUŞ*
}

Ayşe ERGÜL ${ }^{* *}$

\section{$\ddot{O Z E T}$}

Dünya genelinde yaşanan küreselleşme ve küreselleşmenin getirdiği ekonomik ve teknolojik gelişmeler, satış fiyatının piyasada belirlenmesi, satış fiyatı ve karın kontrol edilemeyen değişkenlerken maliyetin işletmenin kontrol edebileceği tek değişken olması ile sonuçlanmıştır. Bu koşullar altında geleneksel maliyet yöntemleri özellikle maliyet düşürme noktasinda yetersiz kalmış, çağdaş maliyet yöntemleri olarak adlandırlan yöntem, teknik ve modeller geliştirilmiş ve kullanılmaya başlanmiştır.

Çalışmanın amacı, hedef maliyetleme, değer analizi ve kaizen maliyetleme yöntemlerini entegre bir şekilde kullanarak hizmet maliyetleri oluşmadan önce belirlemek ve belirlenen hedef maliyette hizmet üretebilmek için gerekli maliyet minimizasyonunu sağlamaktır. Bu amaçla, Antalya'da faaliyet gösteren 5 yıldızlı bir konaklama işletmesinde alan araştırması yapılmıştır. Araştırma sonucuna göre, müsteri istek ve beklentilerine uygun hizmet üretebilmek ve hissedarların arzuladiğ karl elde edebilmek için konaklama işletmesinin 2014 yılında hangi parçalarda ne tutarda maliyet düşürüleceği ve hangi parçalarda fonksiyonların geliştirileceği belirlenmiştir.

Anahtar Kelimeler: Hedef Maliyetleme, Kaizen Maliyetleme, Konaklama Isşletmeleri.

JEL Sinıflandirması: M41, L83.

\section{A Study Of The Applicability With Target Costing, Value Analysis And Kaizen} Costing Methods In Accommodation Enterprises

\section{ABSTRACT}

Throughout the world the globalization and economic and technological developments brought about by globalization resulted in determination of prices in the market and the only controlled variable costs while the price and the profit of uncontrolled variables. Under these conditions, the traditional cost methods were inadequate especially concerning reduction cost and have been developed and used contemporary cost methods.

The purpose of this study is to determine the cost of services before they occur by integrating target costing, value analysis and kaizen costing methods and is to ensure necessary cost minimization in order to produce services with target cost. For this purpose, a field study was conducted in an 5 star accommodation enterprise operated in Antalya. Having been concluded that, which and how much service parts will be reduced and in which parts functionality will be developed in order to produce services according to customer requirements and expectations and to be able to make profit desires of the shareholders.

Keywords: Target Costing, Kaizen Costing, Accommodation Enterprises.

Jel Classification: M41, L83.

\footnotetext{
*Yrd. Doç. Dr. Ercüment Okutmuş, Akdeniz Üniversitesi Alanya İşletme Fakültesi, ercokut@ hotmail.com

*** Dr. Ayșe Ergül, ayseergl@yahoo.com
} 


\section{GiRiş}

Konaklama işletmeleri, işletmenin büyüklüğü ve coğrafi bölgeye göre değişmekle birlikte öncelikle geceleme (konaklama) olmak üzere yiyecek içecek, eğlence, dinlenme spor faaliyetleri, su sporları, gece kulübü, çocuk kulübü, kongre konferans, nişan dügün gibi çok çeşitli aktiviteleri sunan hizmet işletmeleridir.

Emek yoğun üretim tarzı ile faaliyet gösteren konaklama işletmeleri, müşterilerin sürekli değişen ve gelişen talepleri, ekonomik ve teknolojik gelişmeler, kültürel etkileşimin yoğun olduğu küresel rekabet ortamında müşteri memnuniyeti sağlamak durumundadırlar (Dönmez vd., 2011: 202). Konaklama işletmelerinde de maliyet ve karar alma sürecinde yararlanılacak maliyet bilgileri, diğer işletmelerde olduğu gibi sürdürülebilirlik, karlılık ve rekabet edebilirlik açısından oldukça önemlidir (Çam, 2009: 503-504). Ancak konaklama işletmelerinde oluşan maliyetler, üretimin hizmet olması nedeniyle üretim işletmelerinden ayrılmakta ve farklılıklar göstermektedir. Örneğin konaklama işletmelerinde bir ürün üretilmediği için mamul yoktur. Ayrıca üretilen hizmetin emek yoğun olması diğer bir deyiş ile işçilik maliyetlerinin yüksek olması söz konusudur. Konaklama işletmelerinin üretim işletmelerinden ayrılan bir diğer özelliği ise üretim ve tüketimin eşzamanlı olması dolayısıyla hizmetin stoklanamaz olmasıdır.

Konaklama işletmelerinde ortaya çıkan maliyetler, her şey dahil sistemin hakim olduğu özellikle Akdeniz Çanağında müşterilerin satın aldıkları hizmetler fiyata dahil olduğu için daha önemli hale gelmiştir.

Bugün konaklama sektöründe satış fiyatı, çağdaş iş çevresinde olduğu gibi piyasada, piyasa koşulları ise rakiplerin satış fiyatı ve müşteri beklentilerine göre belirlenmektedir. Kar ise işletme ortaklarının beklentileri doğrultusunda oluşmaktadır. Dolayısı ile konaklama işletmelerinin de kontrol edebildiği tek değişken maliyetler olmaktadır. Ancak geleneksel maliyet yöntemleri, maliyetlerin tam ve doğru hesaplanması, maliyet yöntemlerinin ihtiyaç duyulan maliyet bilgilerini üretmesi, maliyet kontrolü, minimizasyonu ve etkinliği açısından yetersiz kalmaktadır. Konaklama işletmelerinin, küresel rekabet ortamında rekabet avantajı yakalamak, pazar paylarını koruyup artırmak, ortakları memnun etmek, tur operatörlerine bağımlılığı azaltmak ve en önemlisi müşteri memnuniyeti sağlamak ve müşterilerin istek ve beklentilerini kalite, fonksiyonellik, fiyat/maliyet ve zaman açısından yerine getirmek için etkili maliyet optimizasyonu sağlayacak çağdaş maliyet yöntemlerini kullanmaları gerekmektedir.

Çalışmanın amacı, konaklama işletmelerinde hizmet üretim maliyetlerini oluşmadan önce belirlemek, değer analizi yöntemi ile müşteri istek ve beklentilerine uygun fonksiyonlarda hizmet üretmek, ortakları memnun edecek hedef kara ulaşmak için kaizen maliyetleme yöntemi ile maliyet minimizasyonu ve etkinliği sağlamaktır. $\mathrm{Bu}$ amaçla Antalya'da faaliyet gösteren 5 yıldızlı bir konaklama işletmesinde alan araştırması gerçekleştirilmiştir. Konaklama işletmesinin ürettiği hizmet fonksiyonlarının görece önemi belirlenirken değer analizi yöntemi kullanılmıştır. İşletmenin 2014 yılı hedef maliyeti 20132014 y1lı maliyet bilgilerine hedef maliyetleme yöntemi uygulanarak belirlenmiştir. 
İşletmenin 2014 yılında hedeflediği karlılığa ulaşması için ne kadar maliyet düşürmesi gerektiği kaizen maliyetleme yöntemi ile hesaplanmıştır. Araştırma sonucunda konaklama işletmesinin 2014 yılında hedef satış fiyatında ortakların hedeflediği karlılığa ulaşmak için toplamda 1.091.877 TL maliyetlerini düşürmesi gerektiği bulunmuştur.

Araştırma literatür ve uygulama bölümü olmak üzere iki bölümden oluşmaktadır. Literatür bölümünde hedef maliyetleme ve kaizen maliyetleme yöntemleri kısaca irdelenmiş ve hedef maliyetleme yöntemi, değer analizi ve kaizen maliyetleme yöntemlerinin entegrasyonu açıklanmıştır. Uygulama bölümde ise elde edilen bulgularla maliyet yöntemlerinin entegrasyonu yapılarak hesaplanmış ve analizler yorumlanmıştır.

\section{HEDEF MALIYETLEME}

1960’l1 yıllarda Japonya' da Toyota işletmesi tarafından geliştirilen hedef maliyetleme, ürün/hizmet maliyetlerini üretime geçilmeden tasarım aşamasındayken hesaplayan, böylece ürün/hizmet maliyetlerini oluşmadan kontrolüne olanak sağlayan piyasa yönlendirmeli bir kar planlama ve maliyet düşürme yöntemi olarak ortaya çıkmıştır. Diğer bir tanıma göre hedef maliyetleme, ürün yaşam dönemi boyunca oluşan ürün/hizmet maliyetlerini tasarım aşamasında belirlemeye ve düşürmeye odaklanan bir yöntem olarak tanımlanmaktadır (Aldalabeeh, 2012: 125). Genelde yeni ürün geliştirme sürecinde kullanılan hedef maliyetleme mevcut ürünlerde de geliştirme odaklı kullanılabilmektedir (Shank ve Fisher 199: 73).

Hedef maliyetleme sürecinin kavramsal temellerini oluşturan altı temel ilkesi bulunmaktadır (Gopalakrishnan vd., 2007: 38; Man ve Fleşer, 2008: 5; Swenson vd., 2003: 12-13). Fiyata Göre Maliyetleme: ilkesi ile kastedilen fiyatın piyasa kontrolü altında olması ve piyasa tarafından belirlenmesi karın ise ortakların beklentileri ve işletme stratejilerine göre belirlenmesi nedeni ile işletmelerin tek kontrol edebileceği değişkenin maliyetler olduğu temeline dayanmasıdır. $\mathrm{Bu}$ durumda hedef maliyet, maliyet artı yaklaşımından farklı olarak hedef satış fiyatı - hedef kar formülü ile hesaplanmaktadır (Albright, 1998: 14). Müşteri Odaklılık: Müşteriler, işletmenin hedef satış hacmine diğer bir deyişle hedef pazar payına ulaşması için en önemli odak noktasını oluşturmaktadır. Bunun için müşteri taleplerinin istenen özellik, fonksiyon, zaman, kalite ve fiyata göre karşılanması ve bu unsurların maliyet düşürme çalışmalarında sürekli dikkate alınması gerekmektedir (Haşaşoğlu, 2011: 58). Tasarım Odaklılık: Ürün/hizmete ilişkin mühendislik çalışmaları üretim başlamadan önce yapılarak maliyetler ürün/hizmet maliyetleri tasarım aşamasında düşürülmelidir (Swenson vd., 2003: 12). Ürün/hizmet maliyetlerinin \% 80-85'i tasarım aşamasında gelişmekte ve bu aşamada ürün bileşenleri, üretim süreleri, montaj süreleri gibi unsurlar belirlenmektedir. Zaman alıcı ve pahalı değişikliklerin maliyetleri bu aşamada önlenmeye çalışılmakta tasarımdan sonra yapılacak değişiklikler bu değişikliklerin boşa gitmesine neden olmaktadır. Çapraz Fonksiyonlu Takımlar: Tasarım, planlama, ürün geliştirme, üretim, satış ve pazarlama, muhasebe vb. çapraz fonksiyonlu ürün ve süreç ekipleri ürün geliştirme fikrinden nihai ürüne kadar tüm süreçten sorumlu olmaktadır (Ansari vd., 2006: 21; Swenson vd., 2003: 12). Yaşam Dönemine Odaklanma: Hedef maliyetleme, bir ürün/hizmetin satın alma, garanti, onarım gibi 
tüm yaşam dönemi boyunca oluşan maliyetlerini dikkate almaktadır. Temel amaç, hem üretici hem de müşteri açısından yaşam dönemi maliyetlerini en aza indirmektir. Değer Zinciri İlişkisi: Hedef maliyetleme yönteminde hedef maliyete ulaşılması tedarikçiler, müşteriler, dağıtıcılar, hizmet sağlayıcılar gibi hedef maliyetleme sürecine ilişkin unsurların işbirlikçi bir şekilde birlikte çalışmaları sonucu değer zinciri oluşturmaları ile elde edilebilecektir (Swenson vd., 2003: 12).

Hedef maliyetleme yönteminin uygulama süreci konaklama işletmelerinde uzun vadeli satış ve kar amaçlarının belirlenmesi ile başlamaktadır. Ürün/hizmet hatları yeniden belirlendikten sonra hedef satış fiyatı ve hedef kar marjı belirlenmektedir. Hedef satış fiyatından hedef karın çıkarılması sonucu kabul edilebilir maliyete ulaşılmaktadır. Kabul edilebilir maliyet, konaklama işletmesi ve tedarikçilerin maliyet düşürme yetenekleri içermediği için ulaşılması güç bir maliyettir. $\mathrm{Bu}$ nedenle hedef maliyete yükseltilmesi gerekmektedir. Gerçekçi bir hedef maliyet belirlendikten sonra bu hedef maliyetin ayrımlanması gerekir. Çünkü bu maliyet hizmetin bütünü için geçerlidir. Hizmetin hangi parça ve fonksiyonlarının birbiri ile uyumsuz olduğunu, hangi parçanın maliyetinin düşürüleceğini ve hangi parçada fonksiyonellik geliştirileceğini belirleyebilmek için hedef maliyetin fonksiyonlara ayrımlanması gerekir.

Konaklama işletmelerinde hedef maliyetin ayrımlanması sekiz aşamadan oluşmaktadır (Türk, 1999: 204-205): Hizmet fonksiyonlarının belirlenmesi; aşamasında hizmetten beklenen fonksiyonlar tanımlanmakta, listelenmekte, bir form haline getirilmekte ve yoğun olarak pazar araştırması yapılmaktadır. Fonksiyonların görece öneminin belirlenmesi aşamasında hizmetin sahip olacağı fonksiyonlar müşteri gözünde değerlendirilmektedir. Hizmeti oluşturacak parçaların belirlenmesi aşamasında daha önce belirlenen hizmet fonksiyonlarını yerine getirecek parçalar belirlenmekte ve ürünün bir prototipi oluşturulmaktadır. Her bir parçanın maliyetlerinin belirlenmesi aşamasında hizmeti oluşturan parçaların maliyetleri tahmin edilmektedir. Parça işletme içinde üretiliyorsa birim maliyeti tespit edilmekte, dışarıdan alınıyor ise piyasa araştırılarak maliyeti tespit edilmektedir. Hizmeti oluşturan parçaların görece öneminin belirlenmesi aşamasında hizmet fonksiyonları ile hizmet parçaları bir matris üzerinde birleştirilerek aralarında bir ilişki kurulmakta ve her bir parçanın söz konusu işlevi yerine getirmede görece önemi belirlenmektedir. Parçaların hedef maliyet endeksinin oluşturulması aşamasında ise her bir parçanın görece önemi ve hizmet maliyeti içindeki payları oranlanarak parçanın hedef maliyet endeksi tespit edilmektedir. Hedef maliyet endeksi parça ile fonksiyonun uyum içinde olup olmadığını göstermektedir. Bu oranın 1 olması istenmektedir. Hedef maliyet endeksinin optimizasyonu aşamasında önemi ile maliyeti uyum içinde olmayan parçalar için alternatifler üzerinde durulmaktadır. Hedef maliyet endeksi hangi parçanın sorunlu olduğunu göstermekte endeksin 1'den büyük olması durumunda parça ucuz, 1'den küçük olması durumunda ise parça pahalı kabul edilmektedir. Diğer maliyet düşürme girişimleri aşamasında ise endeksin optimizasyonu dışında diğer maliyet tasarruflarının gerçekleştirilmesi için kararlar alınmaktadır (Bozdemir, 2010: 100-102). Sürecin sonunda hedef maliyet endeksinde sapmalar var ise ya müşteri açısından değer 
yaratan fonksiyonlar geliştirilmekte ya da değer yaratmayan fonksiyonlarda maliyet azaltımına gidilmektedir.

Hedef maliyetin ayrımlanması aşamasından önce hizmet fonksiyonlarının ve hizmeti oluşturan parçaların belirlenmesi gerekmektedir. Konaklama işletmeleri açısından bakıldığında hizmetin ilk fonksiyonu konaklama olmaktadır. İşletmenin büyüklügüne göre bu fonksiyonlar yiyecek içecek, dinlenme, eğlenme ve işletme içinde kapalı ve açık alanlarda yapılan çeşitli aktiviteler şeklinde çoğaltılabilir. Konaklama fonksiyonu kendi içinde kat hizmetleri ve ön büro-odalar şeklinde ikiye ayrılabilir. Ancak bu 5 ana fonksiyonda kendi içinde müşteri istek ve beklentilerine göre oluşturulmuş alt fonksiyonlardan oluşacaktır.

Hizmet parçaları, hizmeti oluşturan alt hizmetler ya da faaliyetlerdir. $\mathrm{Bu}$ açıdan bakıldığında bir konaklama işletmesinde öncelikle yapılan faaliyet kat hizmetleri ve ön büro odalar faaliyetini kapsayan konaklama faaliyetidir. Yine işletmenin büyüklüğüne göre bu hizmetler/faaliyetler/parçalar, yiyecek içecek, eğlence, dinlenme, çeşitli aktiviteler şeklinde çoğaltılabilir. $\mathrm{Bu}$ ana parçalar da fonksiyonlarda olduğu gibi alt parça/hizmetlerden oluşmaktadır.

\section{KAİZEN MALIYETLEME}

1900'lü yılların ortalarında Masaali İmai tarafından ilk kez geliştirilen kaizen maliyetleme (Bozdemir ve Orhan, 2011b: 464), bir hedef maliyetin belirlenerek bu hedef maliyete ulaşılması ve maliyet etkinliği sağlanabilmesi için üretim süreçlerinin sürekli iyileştirilmesini amaçlayan küçük ama sık adımlarla sürekli gelişmenin söz konusu olduğu bir yöntem olarak tanımlanmaktadır. Kaizen maliyetleme özellikle maliyetleri düşürmek için kullanılan ve üretimin her aşamasında maliyet indirimlerinin sürekli izlendiği bir yöntemdir.

Kaizen maliyetlemenin temelinde yatan sürekli iyileştirme hedeflerine ulaşmak için sorumluluk en üst düzey yöneticiden en alt kademe çalışana kadar tüm işletme çalışanlarında olmaktadır (Erden, 2004: 161). Yöntemde, sonuçları iyileştirmek, bu sonuca neden olan sürekleri sürekli iyileştirmek ve geliştirmekle elde edilmektedir (Yükçü, 2011: 18). Ayrıca, ürüne değer katmayan faaliyetlerin maliyetlerinin sürekli düşürülmesi, israfin elimine edilmesi ve üretim süreçleri üzerinde sürekli geliştirmeye odaklanılmaktadır (Gürdal, 2007: 160).

Kaizen maliyetleme içinde değerlendirilen kaizen faaliyetleri "spesifik olarak bir ürüne uygulanan" ve "genel olarak tüm sürece uygulanan" kaizen faaliyetleri olmak üzere iki gruba ayrılmaktadır (Altınbay 2006: 105). Birincisi yeni bir ürün üç ay boyunca üretildikten sonra fiili maliyet ile maliyet hedefleri arasındaki farkın fazla olduğu durumlarda uygulanan faaliyetleri içermektedir. İkincisi ise kabul edilebilir maliyete ulaşmak için tahminlenen maliyetle fiili maliyet arasındaki farkı azaltmak için her aşamada uygulanan faaliyetleri içermektedir. Genel kaizen maliyetleme faaliyetlerinde her bölüm için belirlenen maliyet azaltım hedeflerine ulaşmak istenmektedir (Altınbay, 2006: 105; Erden, 2004: 171; Monden ve Hamada 1991: 25). 
Kaizen maliyetleme uygulama süreci aşağıdaki şekilde formüle edilmektedir (Yükçü, 2011: 941):

1. Kişi Başı Son Fiili Maliyet $=\frac{\text { Son Dönemdeki Toplam Fiili Maliyet }}{\text { Son Dönemdeki Satılan Yatak Sayısı }}$

2. Cari Dönemdeki Toplam Tahmini ${ }^{1}$ Maliyet $=$ Kişi Başı Son Fiili Maliyet $*$ Cari Dönemdeki Tahmini Yatak Satışı

3. Cari Dönem Toplam Maliyet Hedef $=$ Hedef Maliyet * Cari Dönem Tahmini Yatak Satış1

4. $\quad$ Cari Dönem Toplam Kaizen Maliyet Hedefi $=$ Cari Dönem Toplam Tahmini Maliyet - Cari Dönem Toplam Hedef Maliyet

5. Tahsis Oranı $=\frac{\text { Bir Bölümün Doğrudan Konrol Ettiği Maliyetler }}{\text { Bölümler Tarafından Doğrudan Kontrol Edilen Maliyetler }}$

6. Bir Bölümün Toplam Kaizen Maliyet Hedefi = Cari Dönem Toplam Kaizen Maliyet Hedefi * Tahsis Oranı

\section{HEDEF MALIYYTLEME, DEĞER ANALIZİ VE KAİZEN MALIYETLEMENIN BİRLIKTE KULLANILMASI}

Hedef maliyetleme, Amerikan kökenli değer mühendisliğinin Japonlar tarafindan dinamik bir maliyet düşürme ve kar planlama şekline dönüştürülmüş şeklindedir (Bozdemir, 2010, s.44). Değer mühendisliği ve değer analizi kavramları birbirlerinin yerine kullanılsa da zaman açısından değer mühendisliği yeni bir ürüne tasarım aşamasında (Gherman, 2011, s.213) değer analizi ise üretime geçildikten sonra kullanılmaktadır (Gürdal, 2007, s.170). Hedef maliyetleme ve değer analizi yöntemleri hizmet fonksiyonlarının görece önem derecelerinin belirlenmesinde kullanılmaktadır. Değer analizi ile müşterilerden hizmet fonksiyonlarını önemine göre derecelendirmeleri istenerek böylece her bir hizmet fonksiyonunun görece önemi belirlenebilmektedir.

Bir ürün zaman akışı açısından ürün geliştirme, tasarım, üretim süreçleri olarak ele alındığında hedef maliyetlemeyi kaizen maliyetleme takip etmektedir (Bozdemir ve Orhan, 2011a: 466). Üretilecek bir ürünün tasarım ve geliştirme aşamalarında başlayan hedef maliyetleme süreci, üretim aşamasında kaizen maliyetleme ile devam etmektedir (Saygın, 2008: 85). Üretim aşamasında üretim maliyetlerinin sürekli iyileştirilmesi amacında olması nedeniyle hedef maliyetlere ulaşmada yardımcı olmakta ve ürün maliyetlerini azaltabilmektedir (Köse, 2002: 100). Japon işletmelerinin toplam maliyet yönetim sistemleri, hedef ve kaizen maliyetlemenin entegre bir şekilde kullanılması ile oluşmaktadır (Monden ve Hamada 1991: 17).

\footnotetext{
${ }^{1}$ Kaizen maliyetleme yönteminin uygulama sürecinde tahmini maliyet ve hedef maliyetler bütçe rakamlarından kullanılır. Ancak çalışmada hedef maliyetleme ve kaizen maliyetleme yöntemi entegre edildiği için tahmini maliyet ve hedef maliyet, hedef maliyetleme yönteminden edinilen rakamlar ve işletme yönetiminden elde edilen tahmini yatak satış rakamları kullanılmıştır.
} 
Hedef maliyetleme genelde tasarım aşamasında uygulanan ve ürün yaşam dönemi boyunca hedeflenen satış fiyatından satıldığında hedeflenen karın elde edilebilmesi için bir ürün/hizmetin maliyetinin ne olması gerektiğini gösteren bir yöntemdir. Ancak hedef maliyetleme yönteminde hizmet fonksiyonlarının görece önemi belirlenirken değer analizi yöntemi hedef maliyetleme ile birlikte uygulanmaktadır. Ayrıca hedef maliyetleme tahminlenen maliyet ile hedeflenen maliyet arasında fark olduğu zaman bunun hizmet parçalarında ne tutarda olacağını göstermemektedir. $\mathrm{Bu}$ durumda, hedef maliyetin ayrımlanması sonucunda belirlenen maliyet endekslerine göre bir bölümde hangi parçalarda maliyetlerin düşürülmesi gerektiği noktasında kaizen maliyetleme yöntemi ile birlikte kullanılmaktadır. Örneğin bir bölümde bir parçanın ya da parçaların hedef maliyet endeksi birden küçükse söz konusu bölümün kaizen maliyet hedefi bu parçalarda gerçekleş̧irilmektedir. Parçaların hedef maliyet endeksi 1'den büyük çıkmış ise fonksiyon geliştirmek için yine kaizen maliyetleme yöntemi kullanılmaktadır.

\section{ARAŞTIRMANIN UYGULAMASI ${ }^{2}$}

\section{a. Araştırmanın Amacı ve Önemi}

Çalışmanın amacı, konaklama işletmelerinde, hedef maliyetleme, değer analizi ve kaizen maliyetleme yöntemlerinin entegrasyonu ile işletmede oluşan maliyetleri tam ve doğru saptayarak maliyet minimizasyonu ve etkinliği sağlamak ve böylece yönetsel kararların doğru alınmasını, hissedarların memnuniyetini ve piyasa beklentilerini karşılamayı sağlamaktır. Bu amaçla Antalya'da faaliyet gösteren 5 yıldızlı bir konaklama işletmesinde çalışmanın uygulaması gerçekleştirilmiştir.

Literatür incelendiğinde konaklama işletmelerinde hedef maliyetleme yönteminin diğer çağdaş maliyet yöntemleri ile birlikte uygulanmasına ilişkin çok az çalışma bulunmaktadır. Çalışma, konaklama işletmelerinin küresel rekabet ortamında faaliyetleri devam ettirebilmeleri ve var olan literatür boşluğunun giderilmesi açısından önem taşımaktadır.

\section{b. Araştırmanın Metodolojisi}

Araştırma yöntemi olarak bir evrenden örneklem almak yerine çalışmanın amaçları ve muhasebe ve finans alanında yazılan tezlerde uygulama eksikliği nedeni ile 5 yıldızlı bir konaklama işletmesinde alan araşıırması yapılmıştır.

Örneklemin evreni yansıtabilmesi için Altunışık vd'nin çalışmasında "Belli Evrenler için Kabul Edilebilir Örnek Büyüklükleri” tablosunda evren 30.000 ise örneklemin 379; evren 40.000 ise örneklemin 380 olması gerekmektedir (Altunışık vd, 2005: 127). Uygulama yapılan konaklama işletmesinde hizmet fonksiyonlarının görece önem dereceleri belirlenirken konaklama işletmesinin 2013 yılı konaklayan 33.043 kişi sayısı ana kütle olarak alınmış ve

\footnotetext{
${ }^{2}$ Çalışmanın uygulama aşamasındaki modeli Ayșe Ergül "Hedef Maliyetleme Çerçevesinde Çağdaş Maliyet Yöntemlerinin Maliyet Etkinliği Boyutunda Entegrasyonu Ve Konaklama İşletmelerinde Uygulanması" 2014 Doktora Tezinden alınmıştır. Uygulama verileri ayrıca başka bir konaklama işletmesinden temin edilmiş ve uyarlanmıştır.
} 
ana kütleden örneklem çekilmek yoluyla 390 kişiye değer analizi uygulanmıştır. Anketlerin geri dönüş oranında \% 2 veri kaybı bulunmaktadır. Buna göre 382 kişinin anketi değerlendirmeye alınmıştır.

\section{c. Uygulama Yapılan İşletmenin Tanıtılması}

Uygulama yapılan konaklama işletmesi Antalya'da faaliyet gösteren 5 yıldızlı bir konaklama işletmesidir. İşletmede toplamda 401 oda bulunmaktadır. İşletmede, 9 restoran ve 8 barda yiyecek içecek hizmetleri vermektedir. İşletmede ayrıca, bowling ve bilardo salonu, su sporları, SPA ve fitness merkezi, dalgıç okulu, tenis, diğer sportif aktiviteler, mini club, çocuk havuzu, mini disko olmak üzere çok çeşitli genel aktiviteler bulunmaktadır.

\section{d. Araştırma Bulgularının Değerlendirilmesi}

Çalışmanın bu bölümünde uygulama yapılan konaklama işletmesinin özellikleri hakkında bilgi verilmiş ve elde edilen bulgular değerlendirilmiştir.

\section{e. Konaklama İşletmesinden Edinilen Maliyet Bilgileri}

Araştırma yapılan konaklama işletmesinin ismi ve maliyet bilgilerini içeren belge ve bilgiler işletme yönetiminin isteği ile stratejik açıdan gerekli görüldüğü için gizlenmiştir. İşletmeden elde edilen bilgiler Tablo 4.1'de özetlenerek gösterilmektedir:

Tablo 1: Konaklama İşletmesi Verileri

\begin{tabular}{|l|r|l|r|}
\hline 2013 Kişi Başı Fiili Satış Fiyatı & 174 & 2013 Satış Gelirleri & 38.250 .000 \\
\hline 2013 Kişi Baş1 Fiili Maliyet & 85,84 & 2013 Satılan Hizmetin Maliyeti & 18.884 .000 \\
\hline 2013 Satılan Yatak Sayısı & 220.000 & 2013 Kat Hizmetleri Toplam Maliyeti & 1.720 .000 \\
\hline 2013 Müşteri Sayıs1 & 35.000 & 2013 Ön Büro-Odalar Toplam Maliyeti & 1.355 .000 \\
\hline 2014 Satışa Hazır Yatak Sayıs1 & 310.000 & 2013 Yiyecek-İçecek Toplam Maliyeti & 12.600 .000 \\
\hline 2014 Tahmini Yatak Satış1 & 250.000 & 2013 Eğlence Toplam Maliyeti & 474.000 \\
\hline 2014 K.Baş1 Hedef Satış Fiyatı & 180 & 2013 Genel Aktiviteler Toplam Maliyeti & 2.735 .000 \\
\hline 2014 Hedef Kar Marj1 & $\% 55$ & & \\
\hline
\end{tabular}

f. Konaklama İşıletmesi Kişi Başı Fiili Satış Fiyatı, Maliyet ve Karın Hesaplanması

Tablo 1'de de görüldüğü üzere konaklama işletmesinin 2013 y1lı satış gelirleri 38.250.000 TL ve 2013 y1lı satılan yatak sayıs 220.000 adettir. Bu durumda konaklama işletmesinin kişi başı fiili satış fiyatı:

Kişi Başı Fiili Satış Fiyatı $=\frac{2013 Y_{1} l_{1} \text { Fiili Satış Gelirleri }}{2013 \text { Yll }_{1} \text { Satılan Yatak Sayısı }}=\frac{38.250 .000}{220.000}=174$ TL

Konaklama işletmesinin 2013 yılı satılan hizmet maliyeti 18.884.000 TL'dir. Kişi başı fiili maliyetler aşağıdaki şekilde hesaplanmıştır:

Kişi Başı Fiili Maliyet $=\frac{2013 Y_{1} l_{1} \text { Fiili Satışların Maliyeti }}{2013 \text { Yll }_{1} \text { Satıllan Yatak Sayısı } 1}=\frac{18.884 .000}{220.000}=85,84 \mathrm{TL}$ 
Hesaplamalardan da görüldüğü üzere uygulama işletmesinin 2013 yılı kişi başı fiili satış fiyatı 174 TL ve 2013 yılı kişi başı fiili maliyeti 85,84 TL'dir. Konaklama işletmesinin 2013 yılında bir kişiden elde ettiği kar ise:

Kişi Başı Fiili Kar = Kişi Başı Fiili Satış Fiyatı - Kişi Başı Maliyet

Kişi Başı Fiili Kar $=174-85,84=88,16$ TL

\section{g. Konaklama İşletmesinin Hedef Maliyetinin Hesaplanması}

Uygulama işletmesinden edinilen bilgilere göre işletmenin 2014 hedef satış fiyatı 180 TL ve hedef kar marj1 \% 55 olarak belirlenmiş ve hedef $\mathrm{kar}=180 * 0,55=99 \mathrm{TL}$ olarak bulunmuştur. İşletmenin hedef maliyeti aşağıdaki şekilde saptanmıştır:

Hedef Maliyet $=$ Hedef Satış Fiyatı - Hedef Kar

Hedef Maliyet $=180-99=81 \mathrm{TL}$

\section{h. Hedef Maliyetin Ayrımlanması}

Hedef maliyetleme yönteminde sadece hedef maliyetin belirlenmesi yeterli olmamakta, hedef maliyetin ayrımlanması da gelmektedir. Bu aşamada tüm üretim için belirlenen hedef maliyet hizmetin parça ve fonksiyonlarına indirgenerek ayrımlanmaktadır.

\section{i. Hizmet Fonksiyonlarının Belirlenmesi}

Çalışmada kullanılan fonksiyonlar aşağıda Şekil 1'de gösterilmektedir:

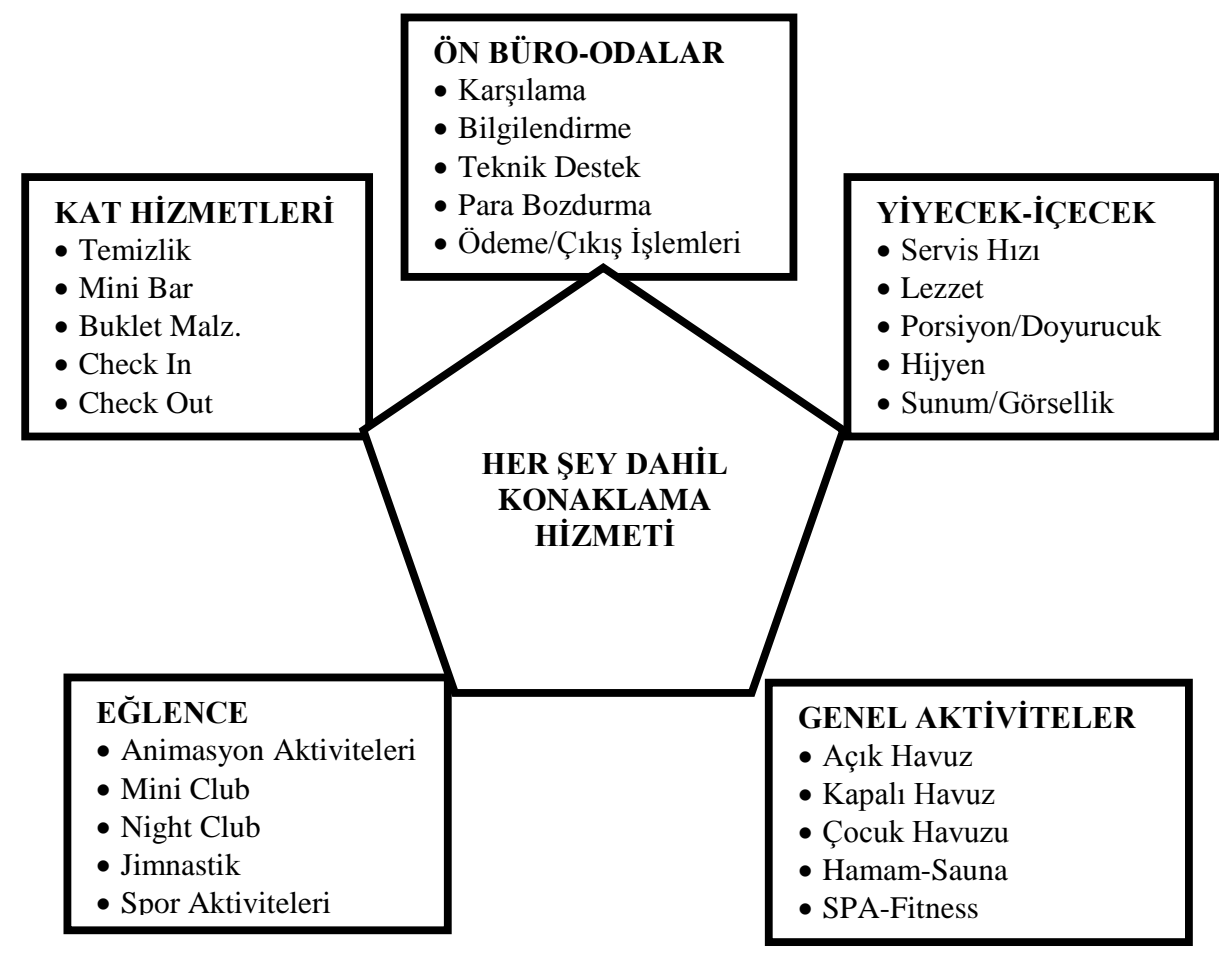

Şekil 1: Konaklama İşletmesi Hizmet Fonksiyonları 
İşletmenin Şekil 1'de görüldüğü üzere ön büro - odalar, kat hizmetleri, yiyecek içecek, eğlence ve genel aktivite fonksiyonları olmak üzere 5 ana fonksiyona ayrılmıştır. Her ana fonksiyon da kendi içinde alt fonksiyonlara bölümlenmiştir. $\mathrm{Bu}$ fonksiyonlar toplandığında işletmenin bütünsel boyutta hizmetini oluşturmaktadır.

\section{ii. Hizmet Fonksiyonlarının Görece Öneminin Belirlenmesi}

Araştırma örneklemi 382 müşteriye uygulanan değer analizi bulgularına göre hizmet fonksiyonlarının görece önem dereceleri aşağıda Tablo 3 'te gösterilmektedir.

Tablo 3: Hizmet Fonksiyonlarının Görece Önem Dereceleri

\begin{tabular}{|c|c|c|c|c|c|}
\hline \multicolumn{3}{|c|}{ Kat Hizmetleri Alt Fonksiyonları } & \multicolumn{3}{|c|}{ Ön Büro Alt Fonksiyonları } \\
\hline \multirow{2}{*}{ Fonksiyonlar } & \multicolumn{2}{|c|}{ Görece Önem Dereceleri } & \multirow{2}{*}{ Fonksiyonlar } & \multicolumn{2}{|c|}{ Görece Önem Dereceleri } \\
\hline & Puan & $\%$ & & Puan & $\%$ \\
\hline Mini Bar & 1.349 & 0,24 & Bilgilendirme & 1.423 & 0,25 \\
\hline Temizlik & 1.102 & 0,21 & Para Bozdurma & 1.321 & 0,23 \\
\hline Check In & 1.156 & 0,20 & Ödeme/Çıkış İşl. & 1.161 & 0,20 \\
\hline Check Out & 1.149 & 0,20 & Karşılama & 973 & 0,17 \\
\hline Buklet Malz. & 869 & 0,15 & Teknik Destek & 852 & 0,15 \\
\hline Toplam & 5.730 & 1 & Toplam & 5.730 & 1 \\
\hline \multicolumn{3}{|c|}{ Yiyecek -İçecek Alt Fonksiyonları } & \multicolumn{3}{|c|}{ Eğlence Alt Fonksiyonları } \\
\hline \multirow{2}{*}{ Fonksiyonlar } & \multicolumn{2}{|c|}{ Görece Önem Dereceleri } & \multirow{2}{*}{ Fonksiyonlar } & \multicolumn{2}{|c|}{ Görece Önem Dereceleri } \\
\hline & Puan & $\%$ & & Puan & $\%$ \\
\hline Hijyen & 1.363 & 0,24 & Spor Aktiviteleri & 1.238 & 0,22 \\
\hline Lezzet & 1.193 & 0,21 & Night Club & 1.206 & 0,21 \\
\hline Porsiyon & 1.083 & 0,19 & Mini Club & 1.121 & 0,20 \\
\hline Sunum & 1.128 & 0,19 & Jimnastik & 1.177 & 0,20 \\
\hline Servis Hiz1 & 963 & 0,17 & Anim. Aktiviteler & 988 & 0,17 \\
\hline Toplam & 5.730 & 1 & Toplam & 5.730 & 1 \\
\hline \multicolumn{3}{|c|}{ Genel Aktiviteler Alt Fonksiyonları } & & & \\
\hline \multirow{2}{*}{ Fonksiyonlar } & \multicolumn{2}{|c|}{ Görece Önem Dereceleri } & & & \\
\hline & Puan & $\%$ & & & \\
\hline Çocuk Havuzu & 1.621 & 0,22 & & & \\
\hline Kapalı Havuz & 1.531 & 0,20 & & & \\
\hline Açık Havuz & 1.546 & 0,20 & & & \\
\hline Hamam/Sauna & 1.445 & 0,19 & & & \\
\hline Spa-Fitness & 1.462 & 0,19 & & & \\
\hline Toplam & 5.730 & 1 & & & \\
\hline
\end{tabular}

Tablo 3'te hizmet fonksiyonlarının görece önem dereceleri bulunmaktadır. hizmet fonksiyonlarının görece önem dereceleri işletmenin müşterilerine anket uygulamasında her bir ana fonksiyonun alt fonksiyonlarını 1-5 arası değerlendirmeleri istenerek elde edilmiştir ve yüzdesel ağırlıklar saptanmıştır. 


\section{iii. Hizmeti Oluşturacak Parçaların Belirlenmesi}

Hizmeti oluşturan parçalar Şekil 2'de gösterilmektedir:

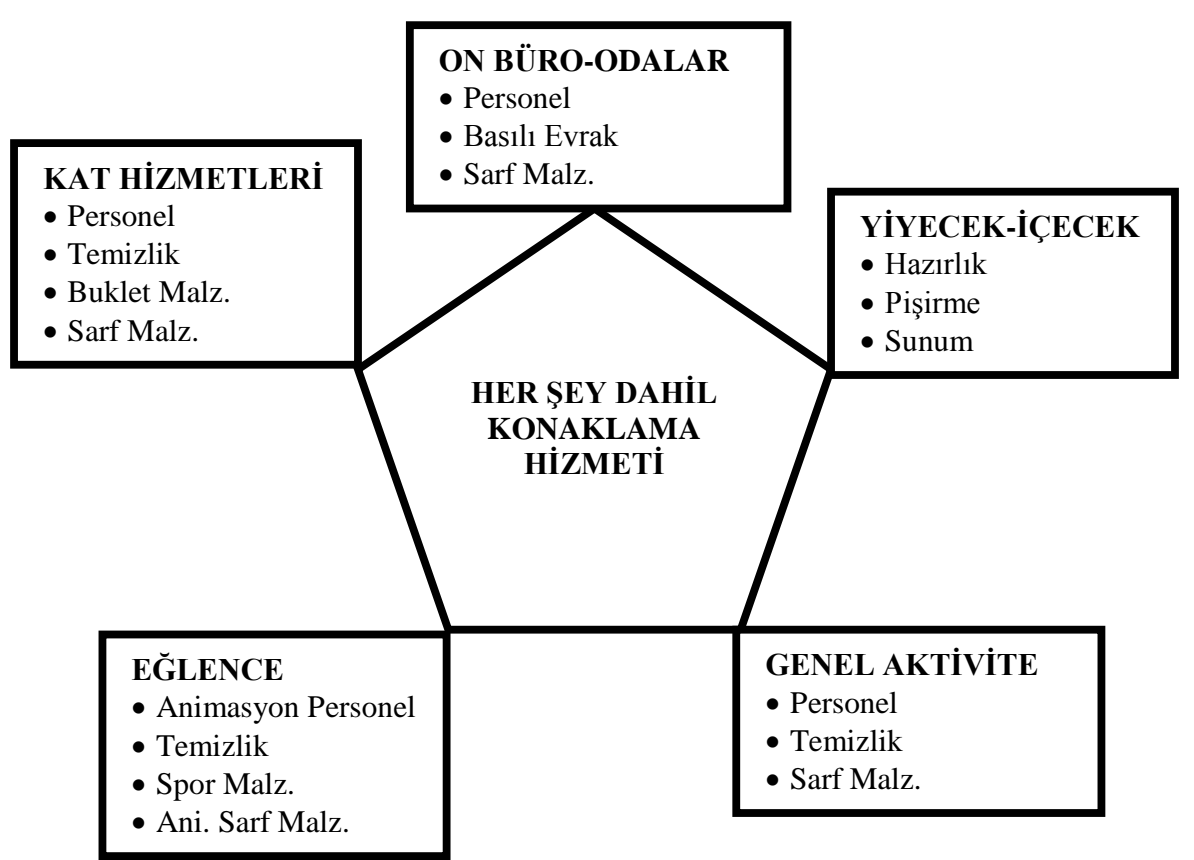

Şekil 2: Konaklama İşletmesi Hizmet Parçaları

Şekil 2'de görüldüğü işletmenin hizmet parçaları 5 ana parça ve alt parçalardan oluşmaktadır. Konaklama işletmelerinin özelliği nedeniyle ana fonksiyonlar aynı zamanda hizmetin parçalarını oluşturmaktadır.

\section{iv. Her Bir Parçanın Maliyetinin Saptanması}

Uygulama otelinden edinilen maliyet bilgilerinden yararlanılarak hizmet parçalarının maliyetleri belirlenmiştir. Buna göre hizmet parçalarının ve parçaları oluşturan alt parçaların maliyetleri ve kendi içerisindeki maliyet payları aşağıda Tablo 4’te gösterilmektedir.

Örneğin kat hizmetleri parçasının alt parçası olan personel parçasının maliyet payı 1.350.000/1.720.000=0,78 olarak hesaplanmıştır. 
Tablo 4: Hizmet Parçalarının Maliyetleri ve Maliyet Payları

\begin{tabular}{|c|c|c|c|c|c|}
\hline \multicolumn{3}{|c|}{ Kat Hizmetleri Alt Parçaları } & \multicolumn{3}{|c|}{ Ön Büro Alt Parçaları } \\
\hline Parçalar & Maliyeti & Maliyet \% & Parçalar & Maliyeti & Maliyet \% \\
\hline Personel & 1.350 .000 & 0,78 & Sarf Malz. & 780.000 & 0,57 \\
\hline Buklet Malz. & 190.000 & 0,11 & Personel & 540.000 & 0,40 \\
\hline Sarf Malz. & 150.000 & 0,09 & Basılı Evrak & 35.000 & 0,03 \\
\hline Temizlik & 30.000 & 0,02 & & & \\
\hline Toplam & 1.720 .000 & 1 & Toplam & 1.355 .000 & 1 \\
\hline \multicolumn{3}{|c|}{ Yiyecek-İçecek Alt Parçaları } & \multicolumn{3}{|c|}{ Ĕglence Alt Parçaları } \\
\hline Parçalar & Maliyeti & Maliyet \% & Parçalar & Maliyeti & Maliyet \% \\
\hline Hazırlık & 8.570 .000 & 0,68 & Personel & 400.000 & 0,84 \\
\hline Sunum & 2.370 .000 & 0,19 & Sarf Malz. & 55.000 & 0,12 \\
\hline Pişirme & 1.660 .000 & 0,13 & Spor Malz. & 13.000 & 0,03 \\
\hline & & & Temizlik & 6.000 & 0,01 \\
\hline Toplam & 12.600 .000 & 1 & Toplam & 474.000 & 1 \\
\hline \multicolumn{3}{|c|}{ Genel Aktiviteler Alt Parçaları } & & & \\
\hline Parçalar & Maliyeti & Maliyet \% & & & \\
\hline Sarf Malz. & 1.790 .000 & 0,65 & & & \\
\hline Personel & 890.000 & 0,33 & & & \\
\hline Temizlik & 55.000 & 0,02 & & & \\
\hline Toplam & 2.735 .000 & 1 & & & \\
\hline
\end{tabular}

\section{v. Hizmeti Oluşturan Parçaların Görece Öneminin Belirlenmesi}

Hedef maliyet ayrımlamasının bu aşamasında hizmet fonksiyonlarının göreceli önem dereceleri ile hizmeti oluşturan parçalar bir matris üzerinde karşılaştırılmıştır. Hem hizmeti oluşturan ana fonksiyonlar hem de parçalar alt fonksiyonlar ve alt parçalardan oluştuğu için üretim işletmelerinin aksine her bir ana fonksiyon ve faaliyeti içeren beş ayrı matris ortaya çıkmıştır.

Tablo 5: Hizmet Alt Parçalarının Görece Önem Dereceleri

\begin{tabular}{|c|c|c|c|c|c|c|}
\hline \multirow[b]{3}{*}{$\begin{array}{c}\text { Kat Hizmetleri } \\
\text { Alt Parçaları }\end{array}$} & \multicolumn{5}{|c|}{ Kat Hizmetleri Alt Fonksiyonlarının Görece Önem Dereceleri } & \multirow{3}{*}{$\begin{array}{c}\text { Parçaların Görece } \\
\text { Önemi } \\
\%\end{array}$} \\
\hline & Temizlik & Mini Bar & Buklet Malz. & Check In & Check Out & \\
\hline & 21 & 24 & 15 & 20 & 20 & \\
\hline Personel & 45 & 70 & 10 & 25 & 25 & 0,38 \\
\hline Temizlik & 45 & 10 & 0 & 25 & 25 & 0,22 \\
\hline Buklet Malzemeleri & 0 & 0 & 90 & 25 & 25 & 0,23 \\
\hline Sarf Malzemeleri $^{3}$ & 10 & 20 & 0 & 25 & 25 & $\mathbf{0 , 1 7}$ \\
\hline TOPLAM & 100 & 100 & 100 & 100 & 100 & $\mathbf{1 , 0 0}$ \\
\hline
\end{tabular}

\footnotetext{
${ }^{3}$ Sarf malzemeleri parçası sarf için kullanılan parçaları ve dışarıdan sağlanan hizmetleri içermektedir.
} 


\begin{tabular}{|c|c|c|c|c|c|c|}
\hline \multirow[b]{3}{*}{$\begin{array}{c}\text { Ön Büro-Odalar } \\
\text { Alt Parçaları }\end{array}$} & \multicolumn{5}{|c|}{ Ön Büro-Odalar Alt Fonksiyonlarının Görece Önem Dereceleri } & \multirow{3}{*}{$\begin{array}{c}\text { Parçaların } \\
\text { Görece Önemi } \\
\% \\
\end{array}$} \\
\hline & Karş11./Yerleş. & Bilgilendirme & Teknik Dest. & Para Bozd. & Öd./Çık. İşl. & \\
\hline & 17 & 25 & 15 & 23 & 20 & \\
\hline Personel & 80 & 90 & 30 & 90 & 80 & 0,77 \\
\hline Basılı Evrak & 10 & 5 & 10 & 5 & 10 & $\mathbf{0 , 0 8}$ \\
\hline Sarf Malzemeleri $^{4}$ & 10 & 5 & 60 & 5 & 10 & $\mathbf{0 , 1 5}$ \\
\hline TOPLAM & 100 & 100 & 100 & 100 & 100 & 1,00 \\
\hline \multirow[b]{3}{*}{$\begin{array}{c}\text { Yiyecek İçecek } \\
\text { Alt Parçaları } \\
\end{array}$} & \multicolumn{5}{|c|}{ Yiyecek İçecek Alt Fonksiyonlarının Görece Önem Dereceleri } & \multirow{3}{*}{$\begin{array}{c}\text { Parçaların } \\
\text { Görece Önemi } \\
\% \\
\end{array}$} \\
\hline & Lezzet & Hijyen & Servis Hızı & Doyuruculuk & Sunum & \\
\hline & 21 & 24 & 17 & 19 & 19 & \\
\hline Hazırlık & 30 & 50 & 60 & 20 & 30 & $\mathbf{0 , 3 8}$ \\
\hline Pişirme & 70 & 35 & 20 & 80 & 30 & 0,47 \\
\hline Sunum & 0 & 15 & 20 & 0 & 40 & 0,15 \\
\hline TOPLAM & 100 & 100 & 100 & 100 & 100 & 1,00 \\
\hline \multirow[b]{3}{*}{$\begin{array}{c}\text { Eğlence } \\
\text { Alt Parçaları } \\
\end{array}$} & \multicolumn{5}{|c|}{ Eğlence Alt Fonksiyonlarının Görece Önem Dereceleri } & \multirow{3}{*}{$\begin{array}{c}\text { Parçaların } \\
\text { Görece Önemi } \\
\% \\
\end{array}$} \\
\hline & Animasyon & Mini Club & Jimnastik & Spor Akt. & Night Club & \\
\hline & 17 & 20 & \begin{tabular}{r|}
20 \\
\end{tabular} & 22 & 21 & \\
\hline Personel & 75 & 75 & 70 & 30 & 20 & $\mathbf{0 , 5 3}$ \\
\hline Temizlik & 5 & 5 & 5 & 5 & 5 & 0,05 \\
\hline Spor Malzemeleri & 10 & 0 & 20 & 60 & 0 & 0,19 \\
\hline $\begin{array}{l}\text { Animasyon Sarf } \\
\text { Malz. }\end{array}$ & 10 & 20 & 5 & 5 & 75 & 0,23 \\
\hline TOPLAM & 100 & 100 & 100 & 100 & 100 & 1 \\
\hline \multirow[b]{3}{*}{$\begin{array}{c}\text { Genel Aktiviteler } \\
\text { Alt Parçaları } \\
\end{array}$} & \multicolumn{5}{|c|}{ Genel Aktiviteler Alt Fonksiyonlarının Görece Önem Dereceleri } & \multirow{3}{*}{$\begin{array}{c}\text { Parçaların } \\
\text { Görece Önemi } \\
\% \\
\end{array}$} \\
\hline & Açık Havuz & Kapalı Havuz & $\begin{array}{l}\text { Çocuk } \\
\text { Havuzu }\end{array}$ & Sauna\&Hamam & Spa\&Fitness & \\
\hline & 20 & 20 & 22 & 19 & 19 & \\
\hline Personel & 20 & 20 & 20 & 60 & 60 & 0,36 \\
\hline Temizlik & 40 & 40 & 40 & 20 & 20 & 0,32 \\
\hline Sarf Malzemeleri $^{6}$ & 40 & $\overline{40}$ & 40 & 20 & 20 & 0,32 \\
\hline TOPLAM & 100 & 100 & 100 & 100 & 100 & 1,00 \\
\hline
\end{tabular}

\footnotetext{
${ }^{4}$ Sarf malzemeleri parçası dışarıdan sağlanan hizmetleri ve malzemeleri de içermektedir.

${ }^{5}$ Animasyon sarf malzemeleri aynı zamanda animasyon için dışarıdan sağlanan fayda ve hizmetleri de içermektedir.

${ }^{6}$ Genel aktiviteler sarf malzemeleri aynı zamanda dışarıdan sağlanan hizmetleri de içermektedir.
} 
Tablo $^{7} 5$ 'te hizmet alt parçalarının göreceli önem dereceleri gösterilmektedir. Okuyucunun hesaplamanın nasıl yapıldığını görmesi için sadece kat hizmetleri personel parçasının görece önemi aşağıda açıklanmaktadır.

Koyu renk marker ile gösterilen yerler kat hizmetleri alt fonksiyonlarının görece önem dereceleridir. Hesaplamanın nasıl yapıldığını açıklamak için kat hizmetleri temizlik fonksiyonu ele alınacak olur ise temizlik fonksiyonunun görece önem derecesi müşterilere yapılan değer analizi sonuçlarına göre \% 21 olarak belirlenmiştir. Temizlik fonksiyonunun ilgili olduğu kat hizmetleri alt parçaları ise diğer bir deyişle temizlik fonksiyonunu karşılayan parçalar ise $\% 45$ oranında personel parçası, $\% 45$ oranında temizlik parçası ve $\% 10$ oranında sarf malzemeleri parçasıdır. Parçaların görece önem dereceleri ise aşă̆ıdaki şekilde hesaplanmıştır:

Kat Hizmetleri Personel Parçası Görece Önem Derecesi $=($ Temizlik fonksiyonu önem derecesi * personel parçasındaki payı) $+($ mini bar fonksiyonu önem derecesi $*$ personel parçasındaki payı) + (buklet malzemeleri fonksiyonu önem derecesi * personel parçasındaki payı $)+($ check in fonksiyonu önem derecesi $*$ personel parçasındaki payl $)+($ check out fonksiyonu önem derecesi * personel parçasındaki payı)

Kat Hizmetleri Personel Parçası Görece Önem Derecesi $=(0,21 * 0,45)+(0,24 * 0,70)+$ $(0,15 * 0,10)+(0,20 * 0,25)+(0,20 * 0,25)=0,38$.

\section{vi. Parçaların Hedef Maliyet Endeksinin Oluşturulması ve Optimizasyonu}

Hizmet parçalarının bir önceki aşamada belirlenen görece önem dereceleri ve her bir parçanın dahil olduğu ana parça içindeki maliyet payı oranlanarak hizmet parçasının hedef maliyet endeksi hesaplanmaktadır. Parçaların hedef maliyet endeksi hangi parçaların maliyetlerinin hedef maliyete ulaşmak için azaltılması gerektiğini ya da hangi parçaların maliyetlerinin sabit tutularak fonksiyonlarının geliştirilmesi gerektiğini belirlemede kullanılmaktadır. Endeks üretilen hizmette neyin değiş̧irilmesi gerektiği ya da hangi parça ve fonksiyonun değiştirilmesi gerektiğini göstermektedir.

Her bir parçanın hedef maliyet endeksinin oluşturulmasında ise aşağıdaki değer endeksi formülü kullanılmıştır:

Parçanın Değer Endeksi $=\frac{\text { Parçanın Görece Önem Derecesi }}{\text { Parçanın Maliyet Ağırı̆̆ı }}$

Hedef maliyet endeksinin 1 olması istenmekle beraber endeksin 1'den büyük olması fonksiyonun ucuz yerine getirildiğini diğer bir deyişle işletmenin söz konusu fonksiyon için müşterinin fonksiyona verdiği değerden daha az maliyete katlandığını bu fonksiyonu geliştirmesi gerektiği; 1'den küçük olması fonksiyonu pahalı yerine getirdiğini diğer bir deyişle konaklama işletmesinin söz konusu fonksiyon için müşterinin verdiği değerden daha fazla maliyete katlandığını ve maliyet minimizasyonuna gitmesi gerektiğini göstermektedir.

\footnotetext{
${ }^{7}$ Hizmet fonksiyonlarının parçalar tarafından yerine getirilme dereceleri konaklama işletmesi yönetiminden temin edilmiştir.
} 
Tablo 6. Hizmet Parçalarının Hedef Maliyet Endeksleri

\begin{tabular}{|c|r|r|r|r|r|r|r|}
\hline \multicolumn{5}{|c|}{ Kat Hizmetleri Parçalarının Hedef } & \multicolumn{3}{c|}{ Ön Büro Parçalarının Hedef Maliyet } \\
Endeksleri
\end{tabular}

Tablo 6' da gösterilen hizmet parçalarının hedef maliyet endekslerinin okuyucuya nasıl hesaplandığını göstermek için sadece kat hizmetleri parçalarının hesaplamaları aşağıda gösterilmektedir.

Kat Hizmetleri Personel Parçası Hedef Maliyet Endeksi $=0,38 / 0,78=0,48$

Kat Hizmetleri Temizlik Parçası Hedef Maliyet Endeksi $=0,22 / 0,02=10,93$

Kat Hizmetleri Buklet Malz. Parçası Hedef Maliyet Endeksi= 0,23/0,11= 0,09

Kat Hizmetleri Sarf Malz. Parçası Hedef Maliyet Endeksi= 0,17/0,09=1,88

\section{vii. Hedef Maliyetin Optimizasyonunda Kaizen Maliyetleme Uygulaması}

Çalışmanın literatür bölümlerinde de açıklandığı gibi hedef maliyetleme bir ürün ya da hizmete tasarım aşamasında kaizen maliyetleme ise üretim aşamasında uygulanmaktadır. Hedef maliyetleme ve kaizen maliyetleme bir birinin alternatifi değil aksine belirlenen hedef maliyetlerin üretim aşamasına geçildiğinde maliyetlerin azaltılması ve fonksiyonelliğin artırılması noktasında birbirinin tamamlayıcısıdır. Hedef maliyetlemede parçaların değer endeksi ile hangi parçalarda maliyet düşürüleceği hangilerinde fonksiyonelliğin geliştirileceğini belirlenebilmekte ancak maliyet düşürülecek parçalarda ne tutarda maliyet düşürüleceği konusunda hedef maliyetleme kaizen maliyetleme ile birlikte kullanılmaktadır 
Çalışmanın kaizen maliyetleme bölümünde yöntemin uygulama sürecinin detaylı bir şekilde açıklanan formülüne dayanarak kaizen uygulaması aşağıdaki şekilde gerçekleştirilmiştir:

Kişi Başı Son Fiili Maliyet $=\frac{\text { Son Dönemdeki Toplam Fiili Maliyet }}{\text { Son Dönemdeki Satılan Yatak Sayısı }}$

Kişi Başı Son Fiili Maliyet $=\frac{18.884 .000}{220.000}=85,84$

Cari Dönemdeki Top. Tah. Mal. = Kişi Başı Son Fiili Mal.* Cari Dön. Tahmini Yatak Satışı

Cari Dönemdeki Toplam Tahmini Maliyet $=85,84 * 250.000=21.460 .000$

Cari Dönem Toplam Maliyet Hedef $=$ Hedef Maliyet $*$ Cari Dönem Tahmini Yatak Satışı Cari Dönem Toplam Maliyet Hedefi $=81 * 250.000=20.250 .000$

Cari Dön. Top. Kaizen Mal. Hedefi = Cari Dön. Top. Tah. Mal. -Cari Dön. Top. Hedef Mal. Cari Dönem Toplam Kaizen Maliyet Hedefi $=21.460 .000-20.250 .000=1.210 .000$

Tahsis oranları, uygulamada işletme, 5 faaliyet alanına/parçaya diğer bir deyiş ile 5 bölüme ayrılması nedeniyle her bölüm için ayrı ayrı hesaplanmıştır.

Tahsis oranı hesaplanırken aşağıdaki formülden yararlanılmıştır:

Bir Bölümün Tahsis Oran $=\frac{\text { BölümünDoğrudan Konrol Ettiği Maliyetler }}{\text { Bölümler Tarafından Doğrudan Kontrol Edilen Maliyetler }}$

Kat HizmetleriTahsis Oran $1=\frac{1.720 .000}{18.884 .000}=0,09$

Ön Büro - Odalar Tahsis Oranı $=\frac{1.355 .000}{18.884 .000}=0,07$

Yiyecek - İçecek Tahsis Oranı $=\frac{12.600 .000}{18.884 .000}=0,67$

Eğlence Tahsis Oranı $=\frac{474.000}{18.884 .000}=0,03$

Genel Aktiviteler Tahsis Oranı $=\frac{2.735 .000}{18.884 .000}=0,14$

Konaklama işletmesi bölümlerinin tahsis oranları belirlendikten sonra her bir bölümün tahsis oranı cari dönem kaizen maliyet düşürme hedefi ile çarpılarak her bir bölümün düşürmesi gereken maliyet hedefleri aşağıdaki şekilde bulunmuştur.

Bölümün Kaizen Mal. Hedefi= Bölümün Tahsis Oranı * Cari Dön. Top. Kaizen Mal. Hedefi

Kat Hizmetleri Kaizen Maliyet Hedefi $=0,09 * 1.210 .000=108.900$

Ön Büro - Odalar Kaizen Maliyet Hedefi $=0,07 * 1.210 .000=84.700$

Yiyecek - İçecek Kaizen Maliyet Hedefi $=0,67 * 1.210 .000=810.700$ 
Eğlence Kaizen Maliyet Hedefi $=0,03 * 1.210 .000=36.300$

Genel Aktiviteler Kaizen Maliyet Hedefi $=0,14 * 1.210 .000=169.400$

Buna göre hedef maliyet endeksi 1'den küçük olan parçalarda o bölümün kaizen maliyet hedefi kadar maliyetler düşürülmeli hedef maliyet endeksi 1'den büyük olan parçaların ise fonksiyonelliği artırılmalıdır.

\section{SONUÇ VE ÖNERILLER}

Çalışmada yapılan hesaplamalar sonucunda elde edilen bulgulara göre ön büroodalarda sarf malzemeleri parçasının; kat hizmetlerinde personel parçasının; yiyecek içecekte hazırlık ve sunum parçalarının; eğlencede personel parçasının; genel aktivitelerde ise sarf malzemeleri parçasının hedef maliyet endeksi birden küçük bulunmuştur. Konaklama işletmesi bu parçalar için müşterinin verdiği değerden daha fazla maliyete katlanmakta ve dolayısı ile bu parçalarda maliyet minimizasyonuna gitmesi gerekmektedir. Öte yandan, ön büro-odalar alt parçalarından personel ve basılı evrak; kat hizmetleri alt parçalarından temizlik, buklet malzemeleri ve sarf malzemeleri, yiyecek-içecek alt parçalarından pişirme; eğlence alt parçalarından temizlik, spor malzemeleri ve sarf malzemeleri ve genel aktiviteler alt parçalarından personel ve temizlik parçalarının hedef maliyet endeksi 1'den büyük bulunmuştur. Yani işletmenin bu parçaların maliyetlerini sabit tutmaya çalışarak fonksiyonelliğini artırması gerekmektedir.

Kaizen maliyetleme uygulamasında ise konaklama işletmesinin 2014 yılı hedef satış fiyatı ve hedef satış hacmi ile hedef kar marjını elde etmek amacıyla belirlenen hedef maliyetlere ulaşmak için toplamda 1.210.000TL maliyet minimizasyonu yapması gerektiği diğer bir deyişle kaizen maliyet hedefi bulunmuştur. Elde edilen bu bulgu tahsis oranı aracılığı ile daha önce belirlenen faaliyet alanlarına/bölümlere/hizmet parçalarına dağıtılmıştır.

Maliyet yöntemlerinin entegrasyonundan elde edilen bulgular aşağıdaki gibidir:

- Konaklama işletmesinin hedef maliyetlere ulaşmak için ön-büro odalar bölümünde hedef maliyet endeksi 1'den küçük olan sarf malzemeleri parçasından 84.700 TL; kat hizmetleri bölümünde personel parçasından 108.900 TL; yiyecek-içecek bölümünde hazırlık ve sunum parçalarından $810.700 \mathrm{TL}$, eğlence bölümünde personel parçasından 36.300 TL ve genel aktiviteler bölümünde sarf malzemeleri parçasından 169.400 TL maliyet minimizasyonuna gitmesi gerektiği ortaya çıkmıştır.

- $\quad$ Ön büro-odalar bölümünde personel ve basılı evrak parçalarının; kat hizmetleri bölümünde temizlik, buklet malzemeleri ve sarf malzemeleri parçalarının, yiyecek-içecek bölümünde pişirme parçasının; eğlence bölümünde temizlik, spor malzemeleri ve sarf malzemeleri parçalarının ve genel aktiviteler bölümünde personel ve temizlik parçalarının hedef maliyet endeksi 1'den büyük gerçekleştiği için bu parçalarda fonksiyonelliğin geliştirilmesi gerektiği anlaşılmaktadır. 
Bu bulgulardan yola çıkılarak işletmede maliyet optimizasyonunun sağlanabilmesi için aşağıdaki öneriler sıralanmaktadır:

Hedef maliyet endeksi 1'den küçük olan parçalarda; kullanarak,

- Kaliteyi bozmadan aynı işlevi yerine getiren daha düşük maliyetli malzemeler

- Konaklama işletmelerinde ilk madde ve malzemelerin her ne kadar işletme bünyesinde üretilmesi mümkün olmasa da ekmek, simit vb yiyecek ürünlerini işletmenin pastane bölümünde üreterek,

- Tedarikçiler ile yeni anlaşmalar yaparak ve/veya yeni tedarikçiler ile çalışarak,

- Müşteri yoğunluğuna göre personel çalıştırarak,

- $\quad$ Yüksek sezonda ekstra olarak adlandırılan personel çalıştırarak

sağlamak,

Düşük sezonda personeli ücretsiz izne göndererek, maliyet minimizasyonu

Hedef maliyet endeksi 1'den büyük olan parçalarda ise,

- $\quad$ Personele bu parça ve fonksiyonlar ile ilgili eğitim sağlamak (örneğin temizlik personelini hijyen ve sanitasyon, ön büro personeline ön büro programları, dil vb konusunda),

- $\quad$ Bir işe bir personel yerine birçok işi yapabilen daha kalifiye ve uzmanlaşmış ancak daha az personel çalıştırarak

- Bazı malzemelerde gramajı azaltıp çeşitliliği çoğaltarak (örneğin buklet malzemeleri, spor malzemeleri ya da yiyecek içecek alanında yiyecek içecek çeşitlerini) fonksiyonelliği artırmak.

İşletmenin vergi sonrası ortalama karının 8.200.000 TL olduğu düşünüldüğünde çalışmanın sonucunda elde edilen 1.210.000 TL kaizen maliyet hedefi ile işletme, 2014 y1lında hedef kara ulaşmak için ortalama olarak \% 15 maliyetlerini düşürmelidir. Böylece işletme hedef satış fiyatında hissedarlara düşen hedef kar düzeyine ulaşacaktır. Müşteri odaklı bakış açısı ile işletme, müşteri memnuniyetinin artması diğer bir deyişle hizmet fonksiyonlarının müşterinin değer verdiği düzeye çıkarılması tur operatörleri açısından işletmenin cazip hale gelmesi anlamına gelecek ve satış fiyatları konusunda işletme üzerindeki tur operatörlerinin fiyat baskısı azalacaktır.

Sonuç olarak, konaklama işletmeleri her ne kadar bugüne değin geleneksel maliyet yöntemleri ile faaliyetlerini sürdürmüş olsalar dahi çağın gereği maliyetlerin tam ve doğru hesaplanması, maliyetleme yöntemlerinin doğru bilgiler vermesi ve stratejik karar almada kilit nokta oluşturması açısından çağdaş yöntemlerin kullanılması gerekmektedir. Çalışmanın maliyet liderliği stratejisi boyutunda devam ettirilmesi ve hedef maliyetleme yönteminin diğer çağdaş maliyet yöntemleri ile entegrasyonunu sağlayarak ileri boyutlara taşınması akademisyenlerin çalışabileceği bir alan olarak görülmektedir. Ayrıca, sektörde çağdaş maliyet yöntemlerini uygulamak isteyen uygulamacılara bu tür çalışmaların nasıl yapılacağı konusunda kaynak sağlanmış olacaktır. Ancak bu işletmelere, bu yöntemlerin 
kullanılmasında, bu yöntemleri doğru bir şekilde uygulayacak kalifiye eleman almaları ve/veya yetiştirmeleri önerilmektedir.

\section{KAYNAKLAR}

Albright, Tom (1998), “The Use of Taget Costing in Developing The Mercedes-Benz M-Class”, International Journal of Strategic Cost Management, Sonbahar, s.13-23.

Aldalabeeh, Abed El Rahman (2012), "Capability of Jordanian Industrial Shareholding Companies to Apply Target Costing System”, International Journal of Business and Management, Cilt. 7, Say1. 21, s. 124-130.

Altınbay, Ali (2006), "Kaizen Maliyetleme Sistemi: Dinamik Bir Maliyet Yönetimi Sistemi”, Afyon Kocatepe Üniversitesi İ.İ.B.F. Dergisi, Cilt. 8, Say1. 1, s. 103-121.

Altunışık, Remzi - Coşkun, Recai. - Bayraktaroğlu, Serkan. - Yıldırım, Engin (2005), Sosyal Bilimlerde Araştırma Yöntemleri: SPSS Uygulamalı, Sakarya Kitabevi, Sakarya.

Ansari, Shadid. - Bell, Janice- Swenson. Dan (2006), “A Template for Implementing Target Costing”, Cost Management, Cilt. 20, Sayı. 5, s. 20-27.

BOZDEMIR, Enver (2010), "Rekabet Üstünlüğü Açısından Hedef ve Kaizen Maliyetleme Yöntemlerinin Türk Otomotiv Sektöründe Uygulanabilirlik Düzeyinin İncelenmesi”, Atatürk Üniversitesi Sosyal Bilimler Enstitüsü, Basılmamış Doktora Tezi, Erzurum.

Bozdemir, Enver. - Orhan, Suphi (2011a), "Üretim Maliyetlerinin Düşürülmesinde Kaizen Maliyetleme Yönteminin Rolü ve Uygulanabilirliğine Yönelik Bir Araştırma”, Atatürk Üniversitesi Sosyal Bilimler Enstitüsü Dergisi, Cilt. 15, Sayı. 2, s. 463-480.

Bozdemir, Enver. - Orhan, Suphi (2011b), "Maliyet Kontrol Aracı Olarak Hedef Maliyetleme Yönteminin Türk Otomotiv Sanayinde Uygulanabilirlik Düzeyinin İncelenmesi”, Atatürk Üniversitesi İktisadi ve İdari Bilimler Dergisi, Cilt. 25, Say1. 2, s. 163179.

Çam, Mustafa (2009), “Konaklama İşletmelerinde Yiyecek İçecek Maliyet Kontrolünün Önemi ve Akdeniz Bölgesindeki Konaklama İşletmelerinde Bir Anket Çalışması", Mustafa Kemal Atatürk Üniversitesi Sosyal Bilimler Enstitüsü Dergisi, Cilt. 6, Sayı. 11, s. 503-524.

Dönmez, Adnan - Arıcı Ali. - Kutluk Filiz (2011), “Antalya'daki Beş Yıldızlı Konaklama İşletmelerinde Yiyecek-İçecek Maliyet Kontrolü ve Fiyatlama Uygulamaları Üzerine Bir Araştırma”, Uluslararası Alanya İşletme Fakültesi Dergisi, Cilt. 3, Sayı. 1, s. 201222.

Erden, Selman Aziz (2004), Üretim Ortamları Maliyet Yönetim Sistemleri İlişkisi ve Stratejik Maliyet Yönetimi, Türkmen Kitabevi, İstanbul.

Gherman, Corina (2011), "Management Marketing Value Engıneering And Firm Performance”, Lucrări Ştiinţifice, Cilt. 54, Sayı. 1, s.213-217. 
Gopalakrishnan, Mohan. - Samuels Janet. - Swenson Dan (2007), “Target Costıng at A Consumer Products Company”, Strategic Finance, Say1. Aralık, s. 37-41.

Gürdal, Kadir (2007), Maliyet Yönetiminde Güncel Yaklaşımlar, Siyasal Kitabevi, Ankara.

Haşaşoğlu, Uğur (2011), "Stratejik Maliyet Yönetim Aracı: Hedef Maliyetleme", Karamanoğlu Mehmetbey Üniversitesi Sosyal Bilimler Enstitüsü, Basılmamış Yüksek Lisans Tezi, Karaman.

Köse, Tunç (2002), "Ürün Maliyetlerine Göre Karar Alma Araçları: Ürün Yaşam Seyri Maliyetlemesi, Hedef Maliyetleme ve Kaizen Maliyetleme”, Osmangazi Üniversitesi Sosyal Bilimler Dergisi, Cilt. 3, Sayı. 2, s. 77-103.

Man, Mariana. - Fleşer, Alina (2008), “The Use Of Target-Cost And Target-Price By The Company's Management”, Annals of the University of Petroşani Economics, Cilt. 8, Say1. 2, s. 5-10.

Monden, Yasuhiro. - Hamada, Kazuki (1991), "Target Costing And Kaizen Costing in Japanese Automobile Companies", Journal of Management Accounting Research, Say1. Sonbahar, s. 16-34.

Saygın, Tuğdem (2008), "Stratejik Maliyet Yönetimi Yaklaşımlarından Kaizen Maliyetleme ve Hedef Maliyetlemenin Uygulanabilirliği ve Bir Uygulama”, Çanakkale On Sekiz Mart Üniversitesi Sosyal Bilimler Enstitüsü, Basılmamış Yüksek Lisans Tezi, Çanakkale.

Shank J.K.- Fisher J. (1999), "Target Costing As A Strategic Tool", Sloan Management Review, Cilt. 41, Sayı. 1, s. 73-83.

Swenson, Dan. - ANSARİ, Shadid - BELL, Jan. ve KİM, Il-Woon (2003) "Best Practices in Target Costing”, Management Accounting Quarterly, Cilt. 4, Sayı. 2, s.12-17.

Türk, Zeynep (1999), “Activity-Based Costing: A Tool for Manufacturing Excellence”, Dokuz Eylül Üniversitesi İ.İ.B.F.Dergisi, Cilt. 14, Sayı. 1, s. 199-214.

Yükçü, Süleyman (2011), Yönetim Açısından Maliyet Muhasebesi, Altın Nokta Basım Yayın, İzmir. 